\title{
Principles of the analysis of structure of chaffinch song (Fringilla coelebs L.). Individual variability of song
}

\author{
Olesya Astakhova, Irina Byome
}

Department of Vertebrate Zoology, Biology Faculty, Moscow State University of M. V. Lomonosov, Moscow, Russia; beme@,nm.ru, chaffinch@,bk.ru

Received 27 January 2012; revised 25 April 2012; accepted 12 May 2012

\begin{abstract}
Song of birds is subtle and flexible species specific feature, like as the morphology signs. Species specific song of chaffinch (Fringilla coelebs L.) can be judged as precise character in the image on sonograms. The song has the certain structure and shares (divides) on the parts, elements, which consists of them. Individual variability of songs of one type will consist in unique singing each of chaffinch males, who form a local population.
\end{abstract}

Keywords: Chaffinch Song; Species Specific Features; Individual Variation of Song; Parts of Song; Polymorphism of Song; Development of Song

\section{INTRODUCTION}

Chaffinch (Fringilla coelebs L.) is one of the first and most widespread objects of researchers of song organizations of birds. Song of chaffinch is genetically determined. And individual variation of genes of song types are presented [1-3].

The resounding and precise song of chaffinch frequently drew attention of bioacoustics as an accessible subject of studying of vocal laws - development of songs in ontogenesis (during life of birds), becoming of vocal repertoire, geographical variability of songs and calls (of voice) of birds [4-9].

In the given work, generalizing of principles of song division into structural parts are submitted, the specific features of song types at different chaffinch males are discovered.

\section{MATERIAL AND METHODS}

During the spring period (April-May, 2005) in different points of territory Curonian spit of Baltic sea (the Kalin-ingrad region), where the density of a population of a chaffinch (Fringilla coelebs L.) was the high, tape recorder records of singing males (on the average $n=20$ songs from everyone) are made.

Record has been executed with the help of tape recorder Panasonic RQ-SX95F, of condenser microphone Philips SBC ME570. Further, sonograms of songs were analyzed with the help of computer program AvisoftSaSLab Light. In total it has been analyzed about three thousand songs. Types of songs are marked by Latin letters.

At the quantitative analysis measured both structure of song type as a whole, and its separate phrases (in three parts of songs - started singing, a trill, a final stroke) on different frequency-and-time parameters: length (duration) of song (sec), maximal, minimal and average (median) frequency $(\mathrm{KHz})$, quantity of elements (syllables), length of syllables (sec), intervals between songs (sec).

\section{RESULTS AND DISCUSSION}

On the basis of these data Long time many fans (amateurs) of songs of birds at singing of chaffinch (Fringilla coelebs L.) defined (determined) only a long trill, frequently with the sharp termination (ending) in the end.

In the middle of XX century, bioacoustics have confirmed, that the trill of song has a descending tonality (that is begins higher frequencies and passes in lower) [10]. In result, in a song of chaffinch (Fringilla coelebs L.) three phrases (knee) are allocated (distinguished): the first - usually increasing in a sound, the second - shorter and the constant frequency $(\mathrm{KHz})$, doing (making) a song with clear step-by-step downturn of a sound, and the third - a final stroke (a sharp sound), which can be complex. Also it has been marked, that the given three phrases (knee) of song can be subdivided into the parts, containing different notes (for example, the first phrase was subdivided on 1a and 16).

For the analysis of song structure of birds exist terms of different character: musical (the note, motif) and linguistic (a syllable, a phrase, a strophe or line). Usually both those, 
and others have mixing use - that it is possible to name a phrase, it name also motif or a tune (the certain part of song, that consist from similar sounds - notes or syllables, elements). The full finished song of a bird can be named a strophe (stanza) (song pattern), which is subdivided into phrases or a knee (oscillation) [11].

Also there are songs-variations-different forms of one song pattern, which can be classified in variational lines (rows) [12,13].

On the basis of these data we have tried to analyze songs of chaffinch, which have been recorded in population of Curonian spit ( $\mathrm{N}=153$ of males).

Principles of the analysis of song structure of chaffinch (Fringilla coelebs L.) (our view with a support on references):

1) On perception (recognition) on hearing, the song was subdivided into three parts: the row (number) of whistle sounds (as if started singing), trill sounds (are as though poured each other) and a final stroke (the example of the analysis is shown on more widespread song type C) (Figure 1).

2) Within the limits of these parts of songs on sonograms it is possible to allocate (design) the phrases (the elements similar in the form), in this case a trill includes two phrases in song type $\mathrm{C}$.

3) Elements (syllables) can be simple (started singing and 1-st phrase of trill in song type C) and complex (compound), consisting of two and more subelements (2-nd phrase of trill in song type C).

4) Syllables (elements) are divided (shared) by intervals, but frequently shorter, than at phrases.

5) A final stroke in many types of songs consist of elements (syllables), different in the form (it is possible, therefore it such sharp, remarkable, "bright" on hearing).

At record, songs of one type met in different points of territory (was considered, that belong to repertoires of different males), therefore alongside with the letter were marked by numbers in ascending order (for example, A1, A2, A3, etc.). At the analysis of sonograms of chaffinch songs come to light (reveal) distinctions in their timeand-frequency parameters (at songs of one type)-socalled individual variability. It is possible to show on example of song type C (Figure 2).

Individual variability - we named as variants (versions) of songs of one type, fixed (recorded) in different points of certain territory or in repertoire of one male.

Songs were considered as songs of one type, that had two similar or completely three parts (started singing, a trill, a final stroke), which of them (parts) can be subdivided into phrases (the second order) (Figure 1).

In Figure 2 it is necessary to note, that besides small distinction of forms of elements of different parts of variants of song type $\mathrm{C}$ (of started singing, trill, a final stroke), can meet and in many respects the modified variations of song - dialect forms, for example, song type $C^{*} 11$ (Figure 2). This phenomenon is interesting, that dialects of songs can exist together in one local population, probably, as a result of mixture of traditions of different song cultures during migrations [14,15].

At the quantitative analysis of variants of song type $\mathrm{C}$ (Table 1) were found out, that the greatest distinction in their length, quantity of syllables and intervals between songs at singing. In other parameters is relative uniformity of the data is observed, but there are the values most distinguished from others.

Variational rows (lines) have been made for the majority of song types of chaffinch, which allocated (designed) on Curonian spit of Baltic sea (in sample 22 song types), are especial for those types of songs, which had strong prevalence in a population $(n>15)$. It is possible to present variants of song type $\mathrm{O}$ (Figure 3 ).

Despite of similarity song variants, exists improvisation at singing of different males (especially in a final stroke), forming individual variability of song type $\mathrm{O}$. It is possible any of these similar song forms in further will give the new song type at the development.

\section{CONCLUSIONS}

Thus, song of chaffinch (Fringilla coelebs L.) can consist of three parts: started singing (the row of whistle sounds), trill sounds (an average part) and a final stroke. On sonograms within the limits of each part it is possible to allocate the separate phrases that consist of elements similar in the form.

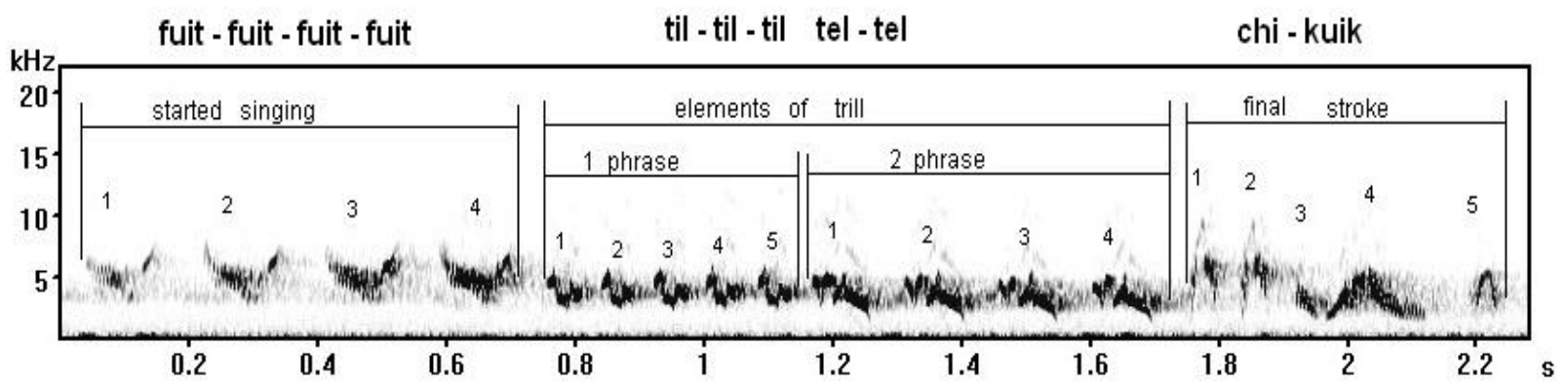

Figure 1. The analysis of structure of song type $\mathrm{C}$ of chaffinch (Fringilla coelebs L.). 


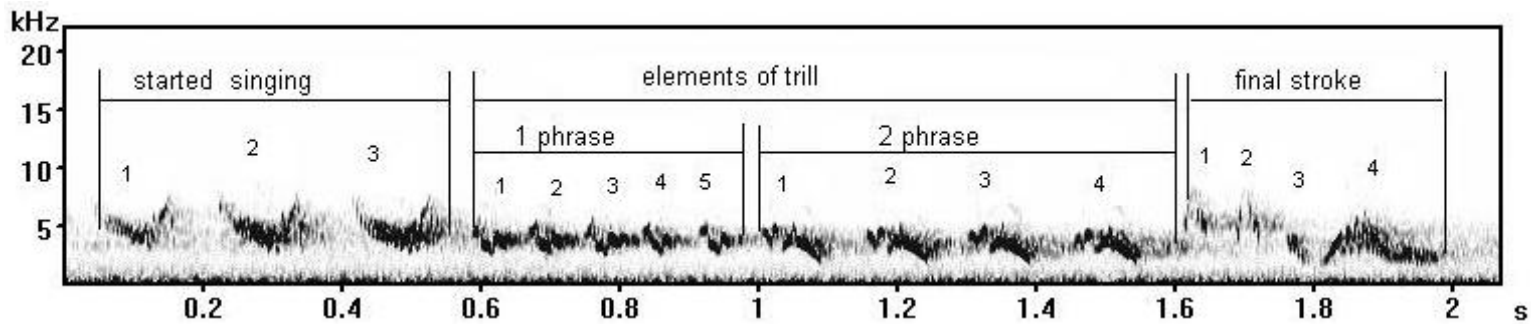

(a)

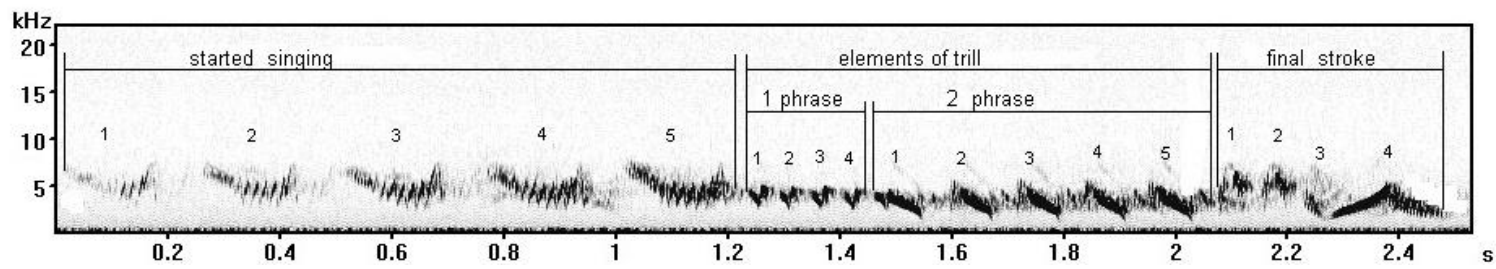

(b)

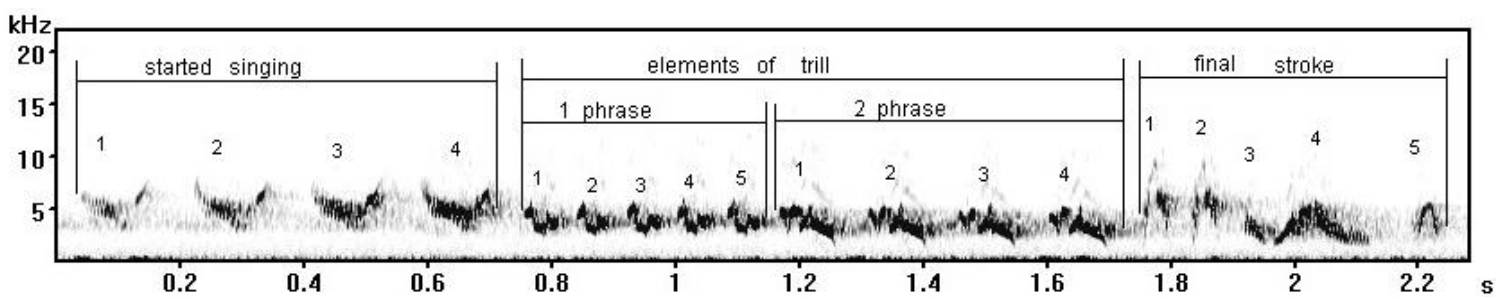

(c)

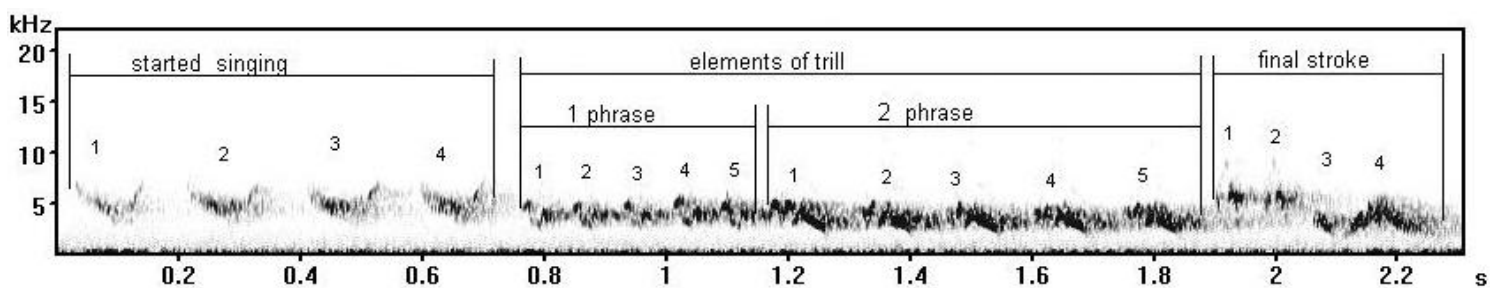

(d)

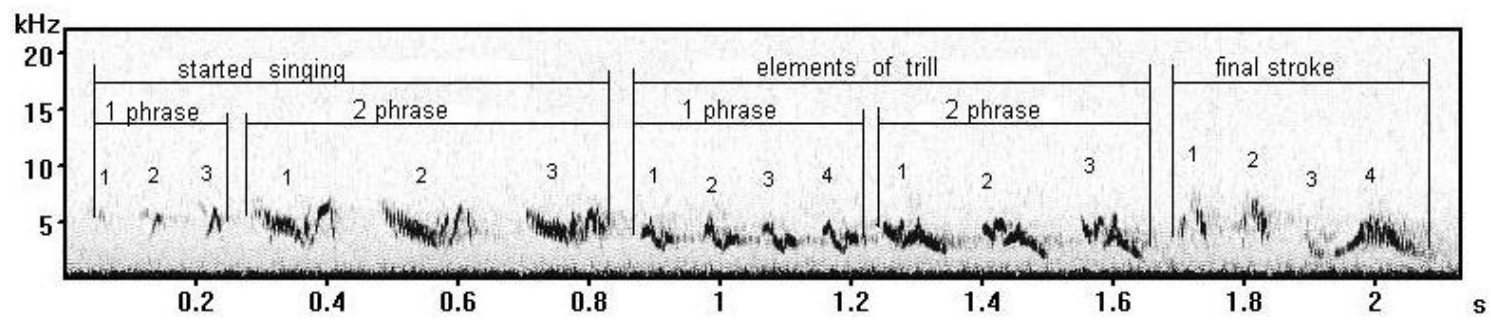

(e)

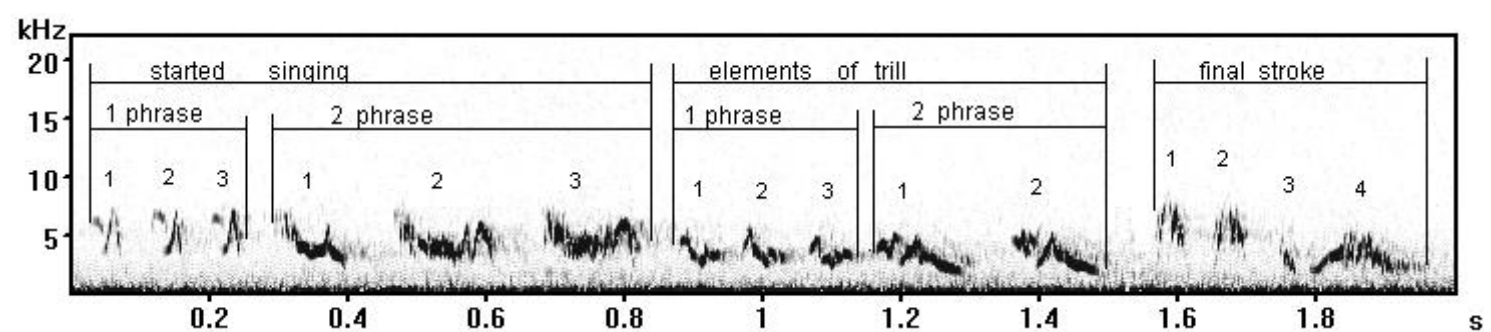

(f)

Figure 2. Variants of song type $\mathrm{C}$ of chaffinch (Fringilla coelebs L.), recorded on territories of Curonian spit in different points: (a) Song type C; (b) Song type C*11; (c) Song type C3; (d) Song type C4; (e) Song type C5; (f) Song type C6. 


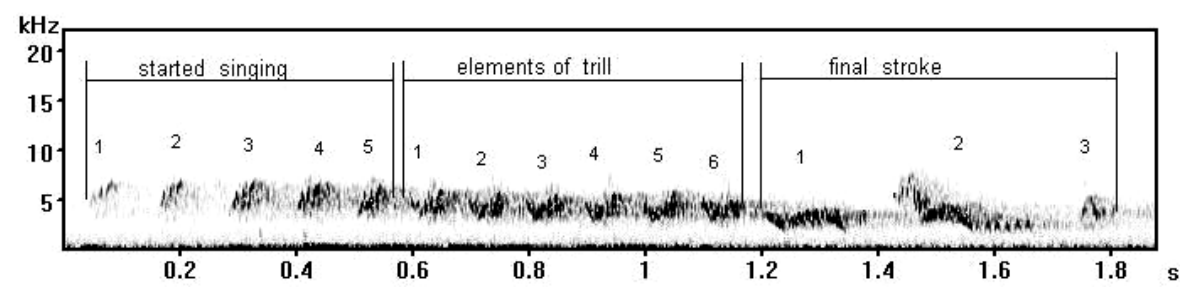

(a)

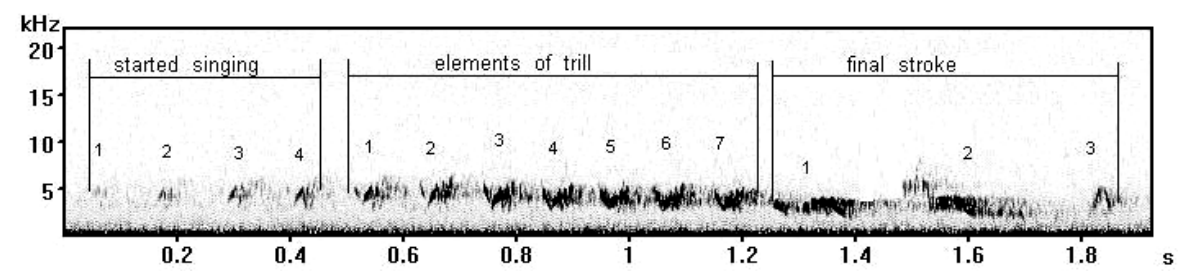

(b)

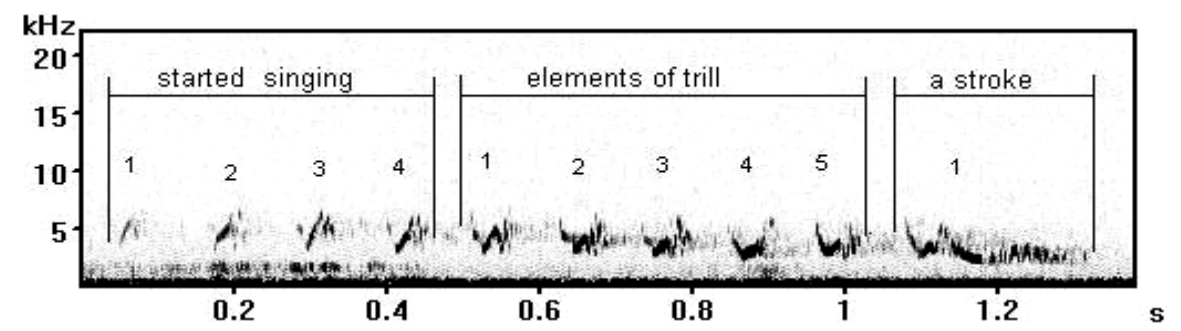

(c)

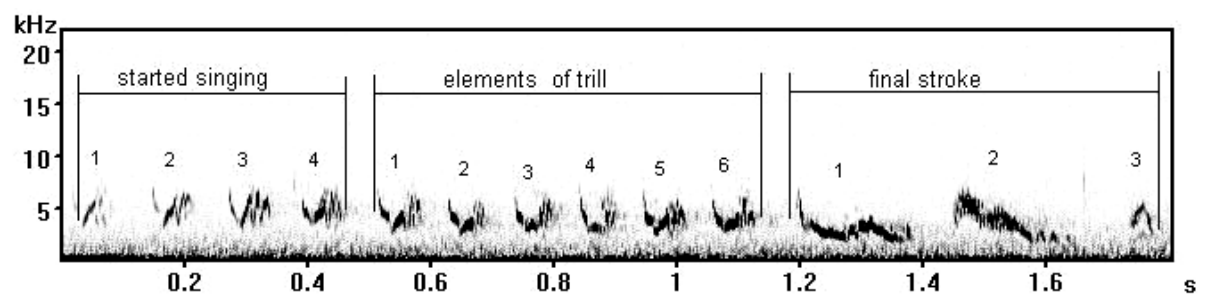

(d)

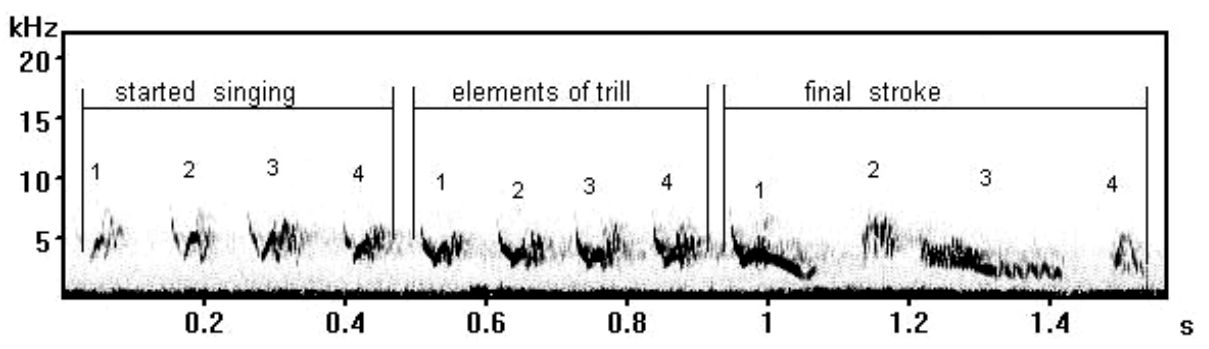

(e)

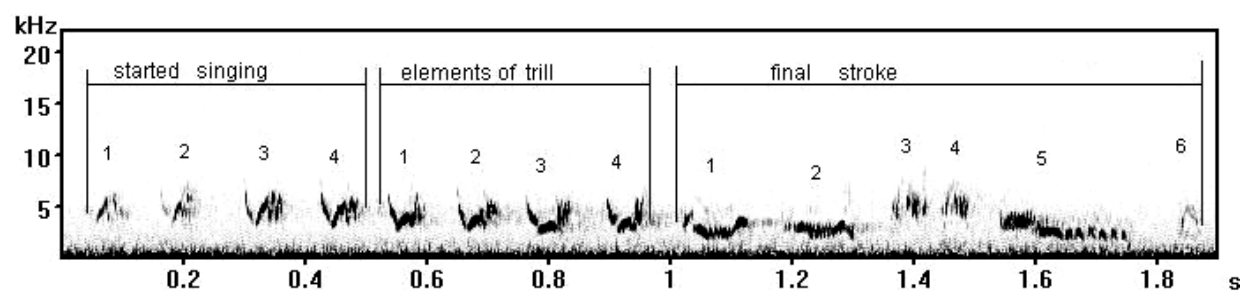

(f)

Figure 3. Variants of song type O of chaffinch (Fringilla coelebs L.), recorded in one local population: (a) Song type O; (b) Song type O1; (c) Song type O2; (d) Song type O3; (e) Song type O4; (f) Song type O5. The identification of individual variation of genes of species-species song. 
Table 1. The basic time-and-frequency characteristics of song type C of chaffinch (Fringilla coelebs L.).

\begin{tabular}{|c|c|c|c|c|c|c|c|c|c|c|c|c|}
\hline \multirow{2}{*}{$\begin{array}{l}\text { Type of } \\
\text { song } \\
\text { (token) }\end{array}$} & \multirow{2}{*}{$\begin{array}{l}\text { Sample } \\
\text { size } \\
\text { (songs) }\end{array}$} & \multirow{2}{*}{$\begin{array}{l}\text { The name } \\
\text { of record } \\
\text { place }\end{array}$} & \multirow{2}{*}{$\begin{array}{c}\text { The length } \\
\text { of song, } \\
\text { sec }\end{array}$} & \multirow{2}{*}{$\begin{array}{c}\text { Min } \\
\text { frequency, } \\
\text { KHz }\end{array}$} & \multirow{2}{*}{$\begin{array}{c}\text { Max } \\
\text { frequency, } \\
\text { KHz }\end{array}$} & \multirow{2}{*}{$\begin{array}{c}\text { Median } \\
\text { (average) } \\
\text { frequency, } \\
\mathrm{KHz}\end{array}$} & \multirow{2}{*}{$\begin{array}{l}\text { Number of } \\
\text { syllables } \\
\text { in song } \\
\text { type }\end{array}$} & \multirow{2}{*}{$\begin{array}{c}\text { Length of } \\
\text { syllables of } \\
\text { start singing, } \\
\text { sec }\end{array}$} & \multicolumn{2}{|c|}{$\begin{array}{l}\text { Length of syllables } \\
\text { trill, } \mathrm{sec}^{*}\end{array}$} & \multirow{2}{*}{$\begin{array}{c}\text { Length of } \\
\text { syllable of } \\
\text { final stroke, } \\
\sec ^{*}\end{array}$} & \multirow{2}{*}{$\begin{array}{c}\text { Intervals } \\
\text { between } \\
\text { songs, } \\
\text { sec }\end{array}$} \\
\hline & & & & & & & & & $\begin{array}{c}1 \\
\text { phrase }\end{array}$ & $\begin{array}{c}2 \\
\text { phrase }\end{array}$ & & \\
\hline $\mathbf{C}$ & 15 & $\begin{array}{l}\text { Trial } \\
\text { point }\end{array}$ & $\begin{array}{l}2.025 \\
\pm 0.11\end{array}$ & $\begin{array}{c}1.447 \\
\pm 0.166\end{array}$ & $\begin{array}{l}8.01 \\
\pm 0.37\end{array}$ & $\begin{array}{c}4.134 \\
\pm 0.215\end{array}$ & $\begin{array}{l}16.7 \\
\pm 1.16\end{array}$ & $\begin{array}{l}0.13 \\
\pm 0.01\end{array}$ & $\begin{array}{c}0.084 \\
\pm 0.028\end{array}$ & $\begin{array}{c}0.13 \\
\pm 0.007\end{array}$ & $\begin{array}{c}0.085 \\
\pm 0.005\end{array}$ & $\begin{array}{l}11.61 \\
\pm 5.06\end{array}$ \\
\hline$C^{*} 11$ & 2 & $\begin{array}{c}2 \\
\text { point }\end{array}$ & $\begin{aligned} & 2.55 \\
\pm & 0.082\end{aligned}$ & $\begin{aligned} & 1.3 \\
\pm & 0.37\end{aligned}$ & $\begin{array}{l}7.751 \\
\pm 0\end{array}$ & $\begin{array}{l}4.478 \\
\pm 0\end{array}$ & $\begin{array}{c}19 \\
\pm 1.4\end{array}$ & $\begin{array}{l}0.175 \\
\pm 0.007\end{array}$ & $\begin{array}{l}0.034 \\
\pm 0.01\end{array}$ & $\begin{array}{c}0.084 \\
\pm 0.001\end{array}$ & $\begin{array}{c}0.915 \\
\pm 0.002\end{array}$ & 22.9 \\
\hline C3 & 20 & $\begin{array}{c}8 \\
\text { point }\end{array}$ & $\begin{array}{c}2.074 \\
\pm 0.118\end{array}$ & $\begin{array}{c}1.627 \\
\pm 0.131\end{array}$ & $\begin{array}{l}9.698 \\
\pm 0.41\end{array}$ & $\begin{array}{r}4.0996 \\
\pm 0.173\end{array}$ & $\begin{array}{l}17.25 \\
\pm 0.85\end{array}$ & $\begin{array}{l}0.1203 \\
\pm 0.005\end{array}$ & $\begin{array}{c}0.068 \\
\pm 0.003\end{array}$ & $\begin{array}{l}0.1155 \\
\pm 0.008\end{array}$ & $\begin{array}{c}0.071 \\
\pm 0.005\end{array}$ & $\begin{array}{l}6.423 \\
\pm 1.9\end{array}$ \\
\hline $\mathrm{C} 4$ & 21 & $\begin{array}{c}9 \\
\text { point }\end{array}$ & $\begin{array}{c}2.01 \\
\pm 0.21\end{array}$ & $\begin{array}{l}1.75 \\
\pm 0.15\end{array}$ & $\begin{array}{l}9.25 \\
\pm 0.6\end{array}$ & $\begin{array}{l}4.056 \\
\pm 0.22\end{array}$ & $\begin{array}{l}16.45 \\
\pm 1.37\end{array}$ & $\begin{array}{l}0.122 \\
\pm 0.01\end{array}$ & $\begin{array}{c}0.066 \\
\pm 0.005\end{array}$ & $\begin{array}{l}0.128 \\
\pm 0.01\end{array}$ & $\begin{array}{c}0.074 \\
\pm 0.008\end{array}$ & $\begin{array}{l}7.06 \\
\pm 0.01\end{array}$ \\
\hline C5 & 6 & $\begin{array}{c}11 \\
\text { point }\end{array}$ & $\begin{array}{l}1.75 \\
\pm 0.15\end{array}$ & $\begin{aligned} & 1.7 \\
\pm & 0.13\end{aligned}$ & $\begin{array}{c}7.8 \\
\pm 0.5\end{array}$ & $\begin{aligned} & 4.3 \\
\pm & 0.07\end{aligned}$ & $\begin{array}{l}13.7 \\
\pm 1.03\end{array}$ & $\begin{array}{c}0.133 \\
\pm 0.005\end{array}$ & $\begin{array}{c}0.067 \\
\pm 0.004\end{array}$ & $\begin{array}{c}0.103 \\
\pm 0.003\end{array}$ & $\begin{array}{c}0.068 \\
\pm 0.005\end{array}$ & $\begin{array}{l}5.4 \\
\pm 0.85\end{array}$ \\
\hline C6 & 3 & $\begin{array}{c}13 \\
\text { point }\end{array}$ & $\begin{array}{l}1.96 \\
\pm 0.12\end{array}$ & $\begin{array}{l}1.55 \\
\pm 0\end{array}$ & $\begin{array}{l}7.522 \\
\pm 0.36\end{array}$ & $\begin{array}{l}4.36 \\
\pm 0.2\end{array}$ & $\begin{array}{l}15 \\
\pm 1\end{array}$ & $\begin{array}{l}0.135 \\
\pm 0.01\end{array}$ & $\begin{array}{c}0.0632 \\
\pm 0.005\end{array}$ & $\begin{array}{l}0.0913 \\
\pm 0.05\end{array}$ & $\begin{array}{c}0.07 \\
\pm 0.006\end{array}$ & $\begin{array}{c}4.44 \\
\pm 0.91\end{array}$ \\
\hline
\end{tabular}

The note: specified are average value and a standard deviation of parameters of song types from statistical calculations for all songs of one type, which were reproduced by chaffinch males in the given points of record; the strongest differences of song types counted a difference of parameters $>0.5 \mathrm{KHz}$ in frequency и $>0.02 \mathrm{sec}$ in length (are allocated by a font); ${ }^{*}$ the trill of song type C consist of two phrases; the values of parameters, most distinguished from others, are separately allocated (designed).

Individual variability of songs of one type exists, but is frequently insignificant. Though in one territory it is possible to meet dialect forms of one song type (enough modified in the form of elements, but having the general (common) similarity in structure).

\section{ACKNOWLEDGEMENTS}

Authors express deep gratitude to employees of a biological research station "Fishing" of the Zoology Institute of the Russian Academy of Science on Curonian spit for the help and support in work, gratitude to prof. G. N. Simkin for valuable advice at the analysis of a material. Work is executed at financial support of the Russian Federal Property Fund, the grant 04-04-49276.

\section{REFERENCES}

[1] Marler, P. (1956) The voice of the chaffinch and its function as a language. Ibis, $\mathbf{9 8 ,} 231-261$. doi:10.1111/j.1474-919X.1956.tb03042.x

[2] Sick, H. (1939) Ueber die Dialektbildung beirn Regenruf des Buchfinken. Journal of Ornit, 87, 568-592. doi:10.1007/BF01950720

[3] Thorpe, W.H. (1958) The leaning of song patterns by birds, with especial reference to the song chaffinch Fringilla coelebs. Ibis, 100, 535-570. doi:10.1111/j.1474-919X.1958.tb07960.x

[4] Promptov, A.N. (1930) Geographical variability of chaffinch song in connection with the general questions of seasonal flights of birds. Zoology Journal, 10, 17-40.

[5] Simkin, G.N. (1983) The typological organization and populational phylogeny of birds song. The bulletin of Moscow society of nature researchers. Section of Biology, 88, 15-27.
[6] Nottebohm, F. (1969) The "critical period" for song leaning in birds. Ibis, 111, 386-387. doi:10.1111/j.1474-919X.1969.tb02551.x

[7] Nottebohm, F. (1967) The role of sensory feedback in development of avian vocalizations. Proceedings of the 14th International Ornithology Congress, Blackwell Science Publishers, Oxford-Edinburg, 265-280.

[8] Slater, P.J.B. and Ince, S.A. (1979) Cultural evolution in chaffinch song. Behaviour, 71, 146-166. doi:10.1163/156853979X00142

[9] Thielcke, G. (1961) Stammesgeschichte und geographische Variation des Gesanges unserer Baumläufer. Verhandlungen der Ornithologischen Gesellschaft in Bayern, 14, 39-74.

[10] Witherby, H.F., Jourdain, F.C.R., Ticehurst N.F. and Tuccker, B.W. (1944) The handbook of British birds. London, 156.

[11] Jellis, R. (1977) Bird sounds and their meaning. Cambridge, 256.

[12] Slater, P.J., Ince, S.A. and Colgan, P.W. (1980) Chaffinch song types: Their frequencies in the population and distribution between repertoires of different individuals. Behaviour, 75, 207-218. doi:10.1163/156853980X00401

[13] Thompson, W.L. (1970) Song variation in a population of indigo buntings. The Auk, 87, 58-71.

[14] Espmark, Y.O., Lampe, H.M. and Bjerke, T.K. (1989) Song conformity and continuity in song dialects of redwings Turdus iliacus and some ecological correlates. Ornis Scand, 20, 1-12. doi:10.2307/3676701

[15] Slater, P.J.B., Clement, F.A. and Goodfellow, D.J. (1984) Local and regional variations in chaffinch song and the question of dialects. Behaviour, 88, 76-97. doi:10.1163/156853984X00498 